\title{
Isolated Unroofed Coronary Sinus without Persistent Left Superior Vena Cava
}

\author{
Tomáš Toporcera, Ján Luczya , Miroslav Gburª, Gabriel Valočík ${ }^{b}$, Adrián Kolesára , \\ František Sabola
}

a Department of Heart Surgery, Medical Faculty, Pavol Jozef Šafárik University and the Eastern Slovak Institute for Cardiovascular Diseases Ltd., Košice, Slovakia

${ }^{b}$ Department of Cardiology, Medical Faculty, Pavol Jozef Šafárik University and the Eastern Slovak Institute for Cardiovascular Diseases Ltd., Košice, Slovakia

\section{ARTICLE INFO}

Article history:

Submitted: 3. 11. 2019

Revised: 7. 1. 2020

Accepted: 8. 1. 2020

Available online: 21. 10. 2020

Klúčové slová:

Defekt predsieňového septa

Echokardiografia

Chirurgia srdca

Nekrytý koronárny sínus
SÚHRN

Nekrytý koronárny sínus (UCS) predstavuje najvzácnejší typ defektu predsieňového septa s incidenciou menej ako $1 \%$ zo všetkých defektov predsieňového septa, alebo menej ako $0,1 \%$ zo všetkých vrodených chýb srdca.

Kazuistika popisuje prípad 57-ročného pacienta, u ktorého bola symptomatológia prítomná štyri roky pred správnym stanovením diagnózy. Pacient udával dlhodobo dýchavičnost', bolesti na hrudníku a v poslednom období bola dokumentovaná prítomnost fibrilácie predsiení. Diagnóza UCS bola určená na základe pravostrannej katetrizácie srdca, echokardiografie a počítačovej tomografie. Pacient podstúpil chirurgický výkon. Vykonaná bola oklúzia defektu s redirekciou koronárneho sínu do l'avej predsiene.

UCS je v 75 \% prípadov spojený s prítomnostou d'alšej vrodenej malformácie srdca, najčastejšie s perzistenciou l'avostrannej hornej dutej žily. Pre izolovaný UCS je prekrytie záplatou zo strany pravej predsiene postačujúcou chirurgickou metódou s dobrými dlhodobými výsledkami. Prítomnost perzistentnej lavostrannej hornej dutej žily vyžaduje technicky náročnejšiu operáciu s oklúziou defektu zo strany l'avej predsiene, alebo s redirekciou lavostrannej hornej dutej žily do pravej predsiene.

() 2020, ČKS.
Keywords:

Atrial septal defect

Echocardiography

Heart surgery

Unroofed coronary sinus

\section{ABSTRACT}

Unroofed coronary sinus (UCS) represents the rarest type of atrial septal defect, with incidence less than $1 \%$ of all atrial septal defects, or less than $0.1 \%$ of all congenital heart anomalies.

A case report of a 57-year-old man with four years of misdiagnosed UCS is presented. The patient showed dyspnoea, angina pectoris, and a new onset of atrial fibrillation. The diagnosis of UCS was finally established on the basis of right-sided cardiac catheterization, echocardiography, and computer tomography. Defect roofing with redirection of the coronary sinus into the left atrium was performed.

UCS is in $75 \%$ of cases associated with other heart anomalies, especially persistent left superior vena cava. For isolated UCS, closing via the path from the side of right atrium is sufficient therapy with good long-term results. Persistence of left superior vena cava requires a technically serious occlusion of the defect from the left atrium or a redirection of the persistent vein itself.

\section{Background}

The incidence of atrial septal defect (ASD) is 3.8 per 10,000 new-borns, corresponding to $5.9 \%$ of all cases of diagnosed congenital heart diseases (CHD). ${ }^{1}$ Thus, ASD is among the most commonly recognized CHD presenting in adulthood. There are five types of ASD with very analogous clinical manifestation, but different embryological aetiology, including primary and secondary ASD, inferior and superior venous septal defect and coronary sinus (CS) defect (Fig. 1). ${ }^{2,3}$ CS atrial septal defect, so-called unroofed CS (UCS), represents the rarest type of ASD, with incidence less than $1 \%$ of all ASD, or less than $0.1 \%$ of all CHD. ${ }^{2}$ During 8 weeks in the embryo, the left anterior cardinal

Address: Tomáš Toporcer, MD, PhD, Department of Heart Surgery, Medical Faculty, Pavol Jozef Šafárik University and the Eastern Slovak Institute for Cardiovascular Diseases Ltd., Ondavská 8, 04001 Košice, Slovakia, e-mail: topyto@gmail.com DOI: $10.33678 /$ cor.2020.002 


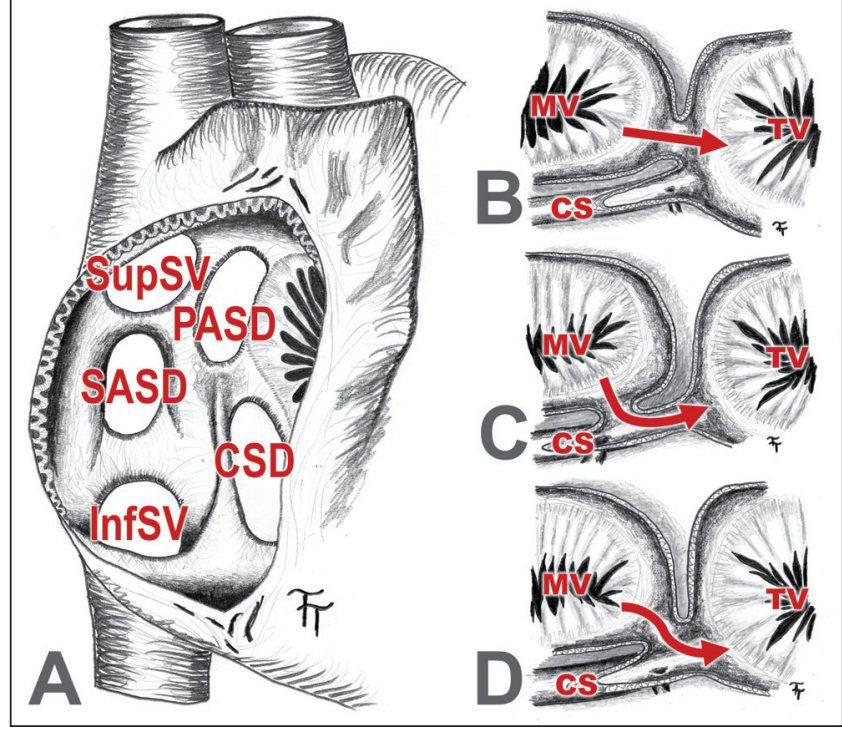

Fig. 1 - (A) Sketch of localization of atrial septal defects (CSD - coronary sinus defect; InfSV - inferior venous septal defect; PASD - primary atrial septum defect; SASD - secondary atrial septum defect; SupSV - superior venous septal defect); (B-D) anatomy of coronary sinus defect subtypes (B - Type I and II - completely unroofed coronary sinus, Type I - with persistent left superior vena cava, Type II - without left superior vena cava; C - Type III - partially unroofed midportion of the coronary sinus; D - Type IV - partially unroofed terminal portion of the coronary sinus) (CS - coronary sinus; MV mitral valve; TV - tricuspid valve).

vein degenerates to the ligamentum of Marshall. ${ }^{4}$ UCS is caused by a defect in the embryonic left-arteriovenous folds forming the wall between the CS and the left atrium. ${ }^{5}$ It is in $75 \%$ of cases associated with persistent left superior vena cava (LSVC) and less often other CHD, including primary ASD, inferior venous septal defect and complex CHD. ${ }^{2,6}$ Anatomically, this diagnosis includes a small or large, single or multiple hole between the atriums in the localization of CS and also an unroofed wall of the very CS with the left atrium - CS communication. ${ }^{3}$ Kouchoukos et al. defined four types of UCS, including complete UCS with persistent LSVC (Type I), complete UCS without LSVC (Type II), a partially unroofed midportion of the CS (Type III) and a partially unroofed terminal portion of the CS (Type IV), whereas the borders between the types are not strictly defined (Fig. 1). ${ }^{6,7}$ The third and fourth types can also be associated with persistent LSVC.

\section{Case report}

A 57-year-old man with dyspnoea, angina pectoris and new onset of atrial fibrillation was admitted to the Department of Cardiology at our institution. During the last four years the patient had undergone recurring hospitalization because of analogous symptoms and suspicion for ASD, acute coronary syndrome and right atrial thrombus. Transthoracic (TTE) and transoesophageal echocardiography (TEE) were repeatedly performed with conclusion of no ASD. Coronarography did not show any stenosis in the coronary arteries.
TTE showed a nondilated left ventricle with normal systolic function (left ventricular ejection fraction of $55 \%$ ), dilated left and right atrium (area of $28 \mathrm{~cm}^{2}$ and $37 \mathrm{~cm}^{2}$ respective in apical four chamber view), dilated right ventricle with normal systolic function (tricuspid annular plane systolic excursion $21 \mathrm{~mm}$ ), mild mitral valve regurgitation, significant tricuspid valve regurgitation, pulmonary artery systolic pressure (PASP) of $45 \mathrm{mmHg}$ and suspicion of UCS. TEE confirmed the presence of ASD in localization between the inferior vena cava and atrioventricular junction with a left-to-right shunt and a diameter of $24 \mathrm{~mm}$ (Fig. 2). Coronarography excluded significant coronary artery stenosis. Right-heart catheterization showed the following oxygen saturation: upper part of right atrium at the entrance of the vena cava superior $-52.7 \%$; middle of the right atrium $-82.5 \%$, distal part of the right atrium $-83.1 \%$ and the inferior vena cava $66.8 \%$, with conclusion of the ASD with Qp/Qs: 3.47 (Fig. 3). Computer tomography (CT) did not showed persistent LSVC and showed dilated UCS with a diameter of $29 \mathrm{~mm}$ and communication between the CS and left atrium with a diameter of $24 \mathrm{~mm}$ (Fig. 3). Surgical intervention was indicated due to UCS.

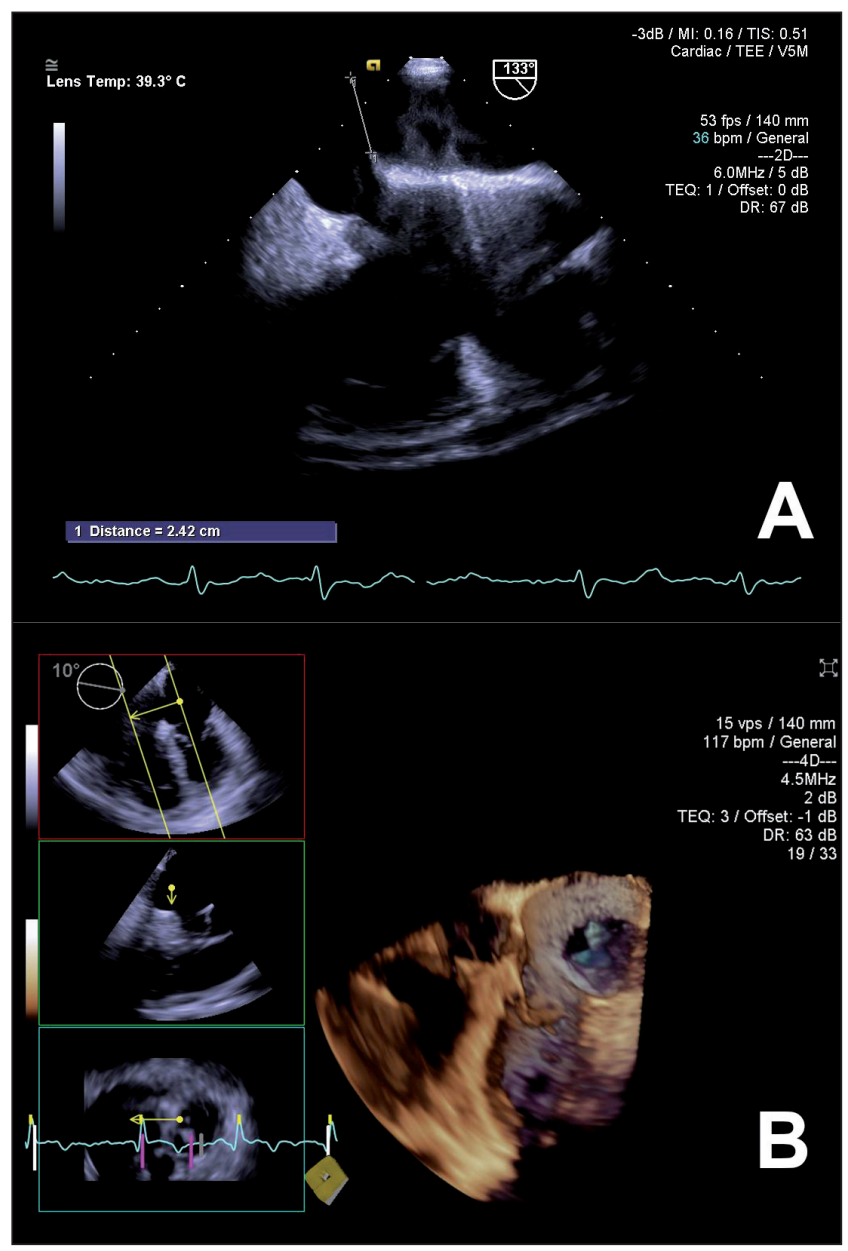

Fig. 2 - (A) TEE in the bicaval projection showing the defect of interatrial septum near to the orifice of the inferior vena cava; (B) 3D TEE picture of the oval defect in down part of the interatrial septum, under the atrioventricular junction, look from the side of the left atrium. 


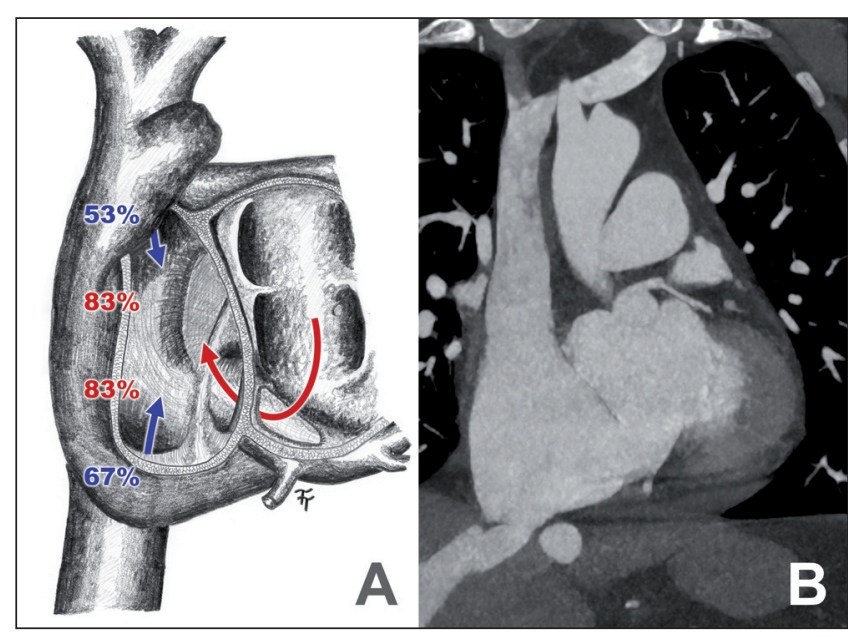

Fig. 3 - (A) Oxygen saturation measured during right heart catheterization and anatomy of the unroofed coronary sinus; (B) computer tomography of the dilated coronary sinus and physiologic right superior vena cava. complications, indication for UCS repair is established when an anomaly is confirmed. ${ }^{4}$ Symptoms can include emboly to the whole body, including the brain with stroke. In general, it is not possible to diagnose UCS according to the symptomatology only. This diagnosis should be suspected, if a left-to-right interatrial shunt or unexplained arterial oxygen desaturation or cerebral complications are presented. ${ }^{6}$ In correlation with the presented case report, more authors state that diagnosis of UCS is very incommodious. ${ }^{6}$ TTE is the widely applied first choice, but deep structure, such as right pulmonary vein and CS, and its relationships with the left atrium are not easily delineated. ${ }^{6}$ On a parasternal long-axis view, a round structure in the posterior-left atrioventricular groove can be a dilated CS. ${ }^{5}$ CS can be visualized with difficulty when the left atrium is enlarged due to other associated cardiac abnormalities. ${ }^{2,4}$ TEE, magnetic resonance imaging (MRI) and three-dimensional echocardiography are more useful for showing this anatomical localization. ${ }^{5,6}$ CT also offers the mapping of this structure. ${ }^{6}$ Some authors point to

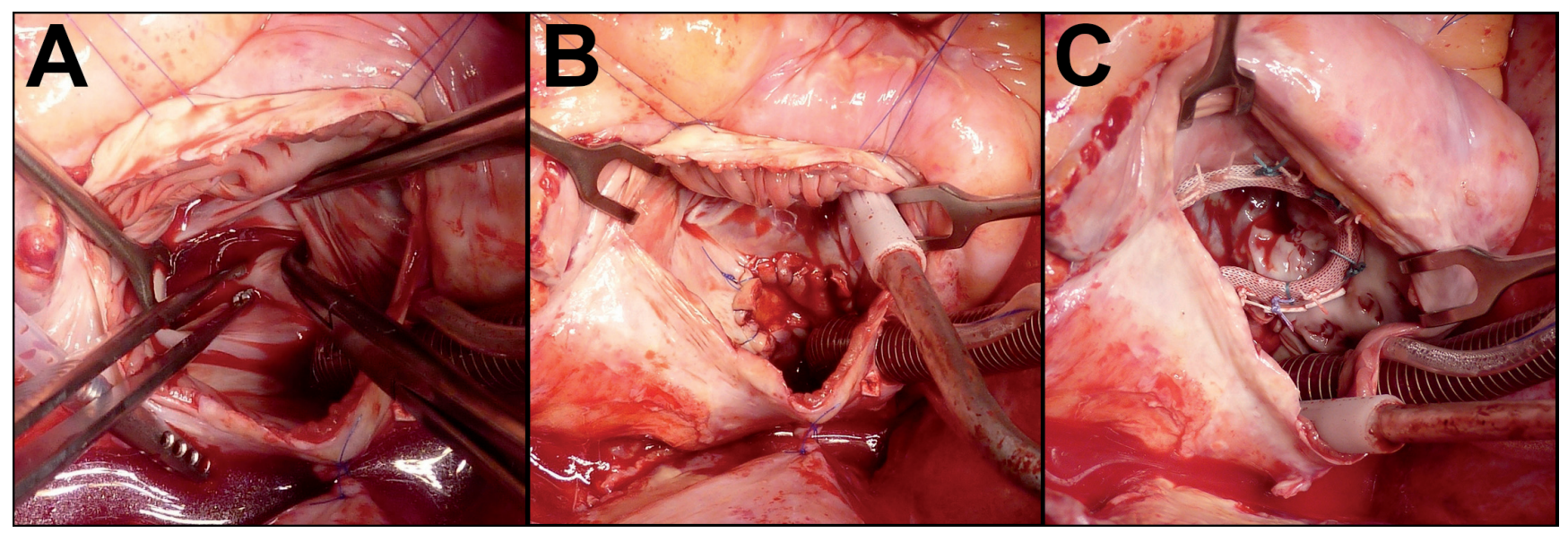

Fig. 4 - Perioperative picture (A): top of Kelly curved forceps points to the left atrium; (B): defect and coronary sinus ostium covered by a pericardial patch; (C): annuloplasty of tricuspid valve.

Standard mid-sternotomy was performed. Afterwards, a cardiopulmonary bypass (CPB) was established in the standard fashion, and the heart was arrested using an anterograde intermittent cold blood cardioplegia. The right atrium of the heart was opened (Fig. 4). ASD was covered by using an autologous patch with derivation of the CS into the left atrium, and annuloplasty of the tricuspid valve was performed (Fig. 4). Duration of the CPB was 87 minutes and aortic clamp time was 52 minutes. The early post-operative period was uneventful. The patient was discharged on the ninth day after surgery.

\section{Discussion}

Symptomatology of the UCS ranges from absolutely asymptomatic diagnosis, which is diagnosed during necropsy, to symptoms of right-sided heart failure from right heart overload. ${ }^{6}$ Management is dependent on the relevancy of symptoms and varies from conservative therapy to acute surgery. ${ }^{6}$ In consideration of deleterious neurological the fact that the use of new diagnostic methods implies that UCS may not be as rare as is assumed. ${ }^{4}$ The presented case shows the repeated misguided negation by TEE of any ASD present. Otherwise, TTE was the first method showing ASD, with very specific definition of the UCS present. Subsequent perplexities in ASD presence were completed only by right heart catheterization and confirmation of the presence of a left-to-right shunt. Bonardy et al. emphasize that anomalous systemic venous return should cause suspicion of UCS presence. ${ }^{6}$ On the other hand, the presented work and some other authors present UCS without persistent LSVC. ${ }^{5}$ The difficulty of diagnosing UCS is also documented by the fact that in only two-thirds of cases is the exact location determined prior to surgery. ${ }^{4}$

Most commonly the CS drains $75 \%$ of cardiac venous circulation into the right atrium. ${ }^{6}$ The LSVS does not regress in $0.5 \%$ of the general population and in the $3-10 \%$ of patients with some form of CHD. ${ }^{6}$ A complex of persistent LSVC and UCS represents $75 \%$ of all UCS and is known as Raghib syndrome. ${ }^{5,8,9}$ The large orifice of the coronary sinus in the terrain of UCS and persistent LSVC 
can lead especially to very close localization of the coronary sinus ostium margin and the atrioventricular node. The atrioventricular node may be situated on the antero-superior margin of the CS. ${ }^{3}$ UCS cannot commonly be treated percutaneously because of the proximity of the surrounding structures, and thus surgical repair with patch closure is performed. If the LSVC is not persistent, many authors recommend defect closure, leaving the CS opening in the left atrium. ${ }^{5,9}$ Moreover, this may be advantageous for cases of right-heart failure and pulmonary hypertension. ${ }^{10} \mathrm{CS}$ flow represents only $4-5 \%$ of circulation and should not affect circulation or cyanosis. ${ }^{2}$ In the field of persistent LSVC, the defect needs to be closed from the side of left atrium strictly in the unroofed part, which maintains drainage of the venous blood from the upper part of the body to the right atrium. Another possibility for this is redirection of the LSVC to the auricula of the right atrium through the transverse sinus with conventional ASD treatment. ${ }^{4,8}$ Redirection of persistent LSVC to the left pulmonary artery in the absence of pulmonary hypertension has also been described. ${ }^{4}$ Zaikokuji et al. present surgery of UCS using a minimally invasive approach and peripheral CPB cannulation. UCS was repaired through the left atrium using a fresh pericardial patch. The use of a minimally invasive technique led to the prolongation of CPB time and aortic clamp time to 290 and 216 minutes. $^{10}$ Additionally, Bozso et al. in 2016 presented this surgery in a 49-year-old woman trough periareolar incision. ${ }^{11}$

\section{Conclusion}

Unroofed coronary sinus is an extremely rare heart congenital anomaly. Due to its localization on the posterior wall of the heart, diagnosis of this defect is very difficult. It is most often based on transoesophageal echocardiography, computer tomography, and magnetic resonance imaging. Proving the left-to-right interatrial shunt by right heart catheterization with the exclusion of other types of atrial septal defects can indicate the presence of just an unroofed coronary sinus. If the unroofed coronary sinus is not associated with other heart anomalies, especially persistent left superior vena cava, closing by the path from the side of right atrium is sufficient therapy with good long-term results. Persistence of the left superior vena cava requires a technically serious occlusion of the defect from the left atrium.

\section{References}

1. Toporcer T, Kolesár A, Ledecký L, et al. Late infective endocarditis of an Amplatzer atrial septal device twelve years after implantation. Cor Vasa 2018;60:e174-e178.

2. Xie MX, Yang YL, Cheng TO, et al. Coronary sinus septal defect (unroofed coronary sinus): echocardiographic diagnosis and surgical treatment. Int J Cardiol 2013;168:1258-1263.

3. Naqvi N, McCarthy KP, Ho SY Anatomy of the atrial septum and interatrial communications. J Thorac Dis 2018;10:S2837-S2847.

4. Chen C, Xu L, Xu Y, et al. Unroofed Coronary Sinus Syndrome: An Easily Corrected Congenital Anomaly But More Diagnostic Suspicion Is Needed. Heart Lung Circ 2018;27:731-738.

5. Quadros SD, Pavithran S, Agrawal R, et al. Coronary sinus atrial septal defect without persistent left superior vena cava: Threedimensional imaging of a rare defect. Ann Pediatr Cardiol 2018;11:103-105.

6. Bonardi M, Valentini A, Camporotondo R Unroofed coronary sinus and persistent left superior vena cava: A case report. J Ultrasound 2012;15:179-182.

7. Kouchoukos NT, Blackstone EH, Hanley FL, et al. Kirklin/ Barratt-Boyes Cardiac Surgery. Philadelphia: Saunders, 2013:2256.

8. Muthialu N, Fajardo D, Sullivan ID, et al. Repair of Persistent Left Superior Vena Cava to Unroofed Coronary Sinus Defect by Retro-Aortic Implantation (Modified Warden Type Procedure). J Card Surg 2016;31:103-105.

9. Rao PS, Harris AD. Recent advances in managing septal defects: ventricular septal defects and atrioventricular septal defects. F1000Res. 2018;7:F1000 Faculty Rev-498.

10. Zaikokuji K, Sawazaki M, Tomari S, et al. Total endoscopic repair of unroofed coronary sinus syndrome via right minithoracotomy. Gen Thorac Cardiovasc Surg 2017;65:206-208.

11. Bozso SJ, Grant A, Iglesias I, et al. Minimally Invasive Periareolar Approach to Unroofed Coronary Sinus Atrial Septal Defect Repair. Ann Thorac Surg 2016;102:e223-e225. 